\title{
СЕРІЯ «Медицина»
}

УДК 614.2

https://doi.org/10.32689/2708-7530-2020-2(2)-114-129

Гбур Зоряна Володимирівна доктор наук 3 державного управління, професор кафедри управління охорони здоров'я Національної медичної академії післядипломної освіти ім. П. Л. Шупика, головний спеціаліст Міністерства фінансів України, вул. Дорогожицька, 9, Київ, Україна 04112, тел. +3080508687675, e-mail: ernest-natan@ukr.net., https//orcid.org/0000-0003-45362438

Щиріна Катерина Василівна аспірантка кафедри управління охороною здоров’я Національної медичної академії післядипломної освіти імені П. Л. Шупика, вул. Дорогожицька, 9, Київ, Україна 04112, тел. +380989792999, еmail:shchyrinak@gmail.com, https://orcid.org/0000-0002-4187-4017

\section{МЕХАНІЗМ ПРОВЕДЕННЯ ЕКСПЕРТНОГО ОПИТУВАННЯ 3 МЕТОЮ ОТРИМАННЯ ЕКСПЕРТНОЇ ОЦНКИ ЩОДО ОСНОВНИХ ПОКАЗНИКІВ ОПТИМІЗАЦІї РОБОТИ БАГАТОПРОФІЛЬНОГО МЕДИЧНОГО ЗАКЛАДУ}

Анотація. Постійні зміни в умовах діяльності закладів охорони здоров'я викликають необхідність додаткового пошуку шляхів ймовірного вирішення проблем для оптимізації показників їх діяльності. Розширення сфери пошуку зумовлює використання для цих потреб процедури експертного опитування, як одного із елементів проведення соціологічних досліджень.

Відтак, виникає необхідність грунтовнішого дослідження механізму проведення експертних опитувань, скоригованих під потреби медичних закладів, зокрема багатопрофільних. На виконання цього, у науковій статті визначено передумови початку застосування даного виду соціологічних досліджень у діяльності медичних установ. Визначено ступінь дослідження зазначеної тематики у науковій літературі із виокремлення раніше не вирішених частин проблеми.

Відображено сутність понять експерт, експертне опитування, а також позитивні аспекти від використання експертних опитувань у діяльності 
установ. Для повноти відображення обраної теми наукового дослідження визначено етапи проведення експертного опитування у багатопрофільній медичні установі із детальним аналізом кожного із них.

Отже, до етапів експертного опитування відносять визначення необхідності його проведення, в частині ідентифікації невирішених проблем, для розв'язання яких необхідна допомога експертів. Другим етапом виступає складання програми та плану опитування, який плавно переходить у етап формування групи експертів, причетних до його проведення. Вибір експертів здійснюється шляхом оцінки їх компетентності об'єктивним або суб'єктивним способом. На цьому ж етапі відбувається безпосередньо процес проведення опитування, методом обраним із наявного переліку та таким, який найбільше підходить під визначену проблему.

Окрім того, в науковій статті нами визначено, що на четвертому етапі проводиться групування та підсумування результатів проведеного опитування, а на п’ятому етапі розрахунок на основі отриманих даних відповідних згрупованих показників, які повинні дати інформацію про ступінь однодумності експертів, а також про ті думки, які виходять за межі стандартних відповідей. На шостому етапі визначається ступінь однодумності думок шляхом розрахунку таких статистичних показників як середнє квадратичне відхилення та коефіцієнт варіації.

Поруч iз цим, у науковій статті, наведено приклад практичного впровадження даних етапів, iз визначенням впливу на діяльність багатопрофільного медичного закладу придбання обладнання для проведення експрес-аналізів. Визначено усереднену відповідь експертів на дану тематику, а також розраховано, що даний задум позитивно вплине на діяльність зазначеного закладу. Відтак, необхідно переходити до етапу його реального придбання, що становить собою сьомий етап експертного опитування, який має назву «Практичне впровадження отриманих результатів». На основі зазначеної інформації сформовано обгрунтовані висновки.

Ключові слова: багатопрофільний медичний заклад, експрес опитування, експерт, експертна оцінка, методи анкетування, дельфійська техніка.

Hbur Zoryana Volodymyrivna Doctor of Science in Public Administration, Professor of the Department of Health Management of the National Medical Academy of Postgraduate Education named after PL Shupyk, Chief Specialist of the Ministry of Finance of Ukraine, Dorohozhytska Street 9, Kyiv, Ukraine, 04112, tel: +3080508687675, e-mail: ernest-natan@ukr.net, https//orcid.org/ 0000-0003-45362438 
Shchyrina Katherine Vasilyevna graduate student of the Department of Health Management of the PL Shupyk National Medical Academy of Postgraduate Education, Dorohozhytska Street 9, Kyiv, Ukraine, 04112, tel: +380989792999, e-mail: Shchyrinak@gmail.com, https:// orcid.org/0000-0002-4187-4017

\title{
MECHANISM OF EXPERIENCE TESTING FOR OBTAINING EXPERT EVALUATION ON THE MAIN INDICATORS OF OPTIMIZATION OF MULTIPROFILE WORK
}

\begin{abstract}
The constant changes in the conditions of activity of healthcare institutions make it necessary to look further for ways of probable problem solving in order to optimize their performance indicators. Expanding the scope of the search causes the use of the expert survey procedure for this purpose as one of the elements of sociological research.

Therefore, there is a need for a more thorough examination of the mechanism of expert surveys, adjusted for the needs of medical institutions, in particular multidisciplinary ones. To do this, the scientific article defines the prerequisites for the beginning of the application of this type of sociological research in the activities of medical institutions. The degree of research of the mentioned subject in the scientific literature is determined to identify previously unresolved parts of the problem.
\end{abstract}

The essence of the concepts of expert, expert survey, as well as the positive aspects of the use of expert surveys in the activities of institutions are reflected. In order to fully reflect the chosen topic of the research, the stages of conducting an expert survey in a multidisciplinary medical institution were determined with a detailed analysis of each of them.

Therefore, the stages of the expert survey include determining the need to conduct it, in terms of identifying unresolved issues that require the assistance of experts. The second stage is the preparation of the program and the survey plan, which gradually goes into the formation of a group of experts involved in its implementation. Experts are selected by assessing their competence in an objective or subjective manner. At the same stage, there is a direct process of conducting the survey, a method selected from the existing list and one that is most suitable for a particular problem.

In addition, in a scientific article, we have determined that the fourth stage is grouping and summarizing the results of the survey, and in the fifth stage, the calculation based on the data obtained relevant grouped indicators, which should give 
information about the degree of unanimity of experts, as well as those opinions that go beyond standard answers. The sixth stage determines the degree of unanimity of thought by calculating such statistical indicators as the root mean square deviation and the coefficient of variation.

In addition, a scientific article provides an example of the practical implementation of these stages, with determining the impact on the activities of a multidisciplinary medical facility to purchase equipment for rapid analysis. The average response of experts to this topic is determined, and it is calculated that this plan will have a positive impact on the activity of the institution. Therefore, it is necessary to proceed to the stage of its actual acquisition, which is the seventh stage of the expert survey, which is called "Practical implementation of the obtained results". Based on the above information, sound conclusions are drawn.

Keywords: multidisciplinary medical institution, express survey, expert, expert evaluation, questionnaire methods, delphic technique.

Постановка проблеми. На сьогоднішній день в Україні активно впроваджується реформа сфери охорони здоров`я, яка передбачає тотальне пере форматування процесу надання медичних послуг, у тому числі шляхом перетворення наявної мережі медичних закладів, надання їм розширеного переліку повноважень, укрупнення наявної мережі закладів охорони здоров’я, тощо. Для того, щоб у результаті цих процесів якість обслуговування населення не погіршилась, а навпаки, долаючи наявні проблеми зазнала змін на краще, необхідно враховувати досвід, напрацьований у сфері надання медичних послуг за роки незалежності, з метою уникнення повторення тотожних помилок, а також орієнтуватися на успішний досвід розвинутих країн у побудові ефективної медичної системи. Цей досвід має як позитивні, так і негативні сторони, що впливають на рівень задоволеності громадян якістю їх обслуговування закладами охорони здоров 'я. 3 метою відстеження проблем, які заважають підвищенню якості надання медичних послуг, часто виникає потреба 3’ясування погляди різних людей з цих питань. В таких умовах виникає потребу у застосування методів соціологічного дослідження, до яких, зокрема, відноситься метод експертного опитування, що в свою чергу зумовлює актуальність даного наукового дослідження.

Аналіз останніх досліджень і публікацій. Питання методологічного забезпечення проведення соціологічних досліджень, зокрема в частині експертних опитувань, розглядаються у працях таких дослідників як: О. Р. Титаренко, І. Р. Верцімага, Н. В. Толстих, Б. Г. Литвак, В. І. Добреньков, Г.М. Гнатієнко А. І. Кравченко, В.В. Рудень, В. Я. Ельмеєв, В. Г., Т.Г. Гутор, 
Овсянников, В.С. Снитюк, С.Е. Зелінський та інші. В Україні протягом останнього часу, підвищилась увага до проведення різного роду опитувань, в тому числі і в медичній сфері. При цьому опитують головним чином пацієнтів закладів охорони здоров я. При цьому такі дослідження здійснюються частіше за все громадськими організаціями або на їх замовлення. Деякі медичні установи також намагаються дослідити думку пацієнтів про ефективність їх роботи, застосовуючи невеликі експрес-опитування. Разом 3 тим, на нашу думку, недостатньо уваги приділено використанню експертного опитування, як інструменту для дослідження проблемних питань у діяльності медичних закладів та використання отриманих даних для розробки пропозиції 3 оптимізації основних показників їх роботи.

Постановка завдання. 3 урахуванням вищенаведеного, метою даного наукового дослідження виступає вивчення наявних підходів до організації експертних опитувань, 3 метою отримання кваліфікованих висновків щодо проблемних тенденцій у діяльності медичних установ та формування заходів для їх усунення.

Виклад основного матеріалу дослідження. Дослідження, які проводяться в медичній сфері, зокрема в умовах активного реформування галузі, часто зумовлюють у дослідників необхідність залучення додаткової інформації, яка може допомогти підтвердити або спростувати сформовані гіпотези та висновки, виявити коло проблем, для вирішення яких необхідне прийняття відповідних управлінських рішень.

Одним 3 джерел отримання такого роду інформації стають експерти (від лат. expertus - досвідчений), тобто спеціалісти у конкретній сфері, які володіють необхідними знаннями та досвідом і здатні аналізувати інформацію, яка до них поступає, та надавати кваліфіковану оцінку об’єкту експертизи у межах своєї компетенції [1, с. 77; 2]. Окрім того, вони також володіють необхідними технологіями та навичками, що використовуються у сфері дослідження і здатні оцінити можливість їх реалізації в межах конкретної ситуації, а також 3 відповідальністю надавати відповідні рекомендації та висновки.

Таким чином, метод експертного опитування - це досить поширений науковий метод, який дає змогу одержати об’єктивну оцінку щодо предмету опитування на основі сукупності особистих думок експертів [3, с. 64]. В той же час, під експертом мається на увазі особа, які передається повноваження на висловлювання думки про якийсь неоднозначний чи нелегкий випадок, процес, ситуацію, адже ще з давніх-давен у складних ситуаціях, як правило, звертались до спеціалістів у сфері виникнення проблеми. 
Як правило, експертні опитування проводяться в комплексі 3 масовим (соціологічним) опитуванням. Але, в той же час, поширеною $є$ практика їх одиничного використання. Проведення експертних опитувань допомагає інтерпретувати кількісні дані, отримані в результаті масового збору інформації. Думки компетентних фахівців дозволяють сформувати i уточнити дослідні гіпотези, правильно оцінити факти та «суху» інформацію [4; 5].

Якщо говорити про заклади охорони здоров’я, то даний метод доцільно застосовувати для пошуку проблем у їх діяльності на шляху до оптимізації роботи медичного закладу, особливо в умовах активного етапу реформи медичної галузі. Проте, часом експертне опитування доцільно проводити, навпаки, не результатів проведення змін для пошуку вже сформованих проблем, а на самому початку їх запровадження.

Процес проведення експертних опитувань відрізняється, залежності від напрямку на якому він сфокусований. Відтак, механізм проведення експертного опитування націлений на визначення показників оптимізації діяльності багатопрофільного медичного закладу повинен проводитись в декілька етапів, наочне відображення яких отримуємо із рис. 1.

Розглянемо кожен із етапів детальніше. Отже, на першому етапі проведення експертного опитування визначається необхідність його проведення, яка в подальшому слугуватиме основою навколо якої вибудовуватимуться наступні етапи. Такою необхідністю в межах багатопрофільного медичного закладу, який слугує для нас основою для проведення дослідження, виступає:

- наявність практики невдоволеності пацієнтів отриманими послугами;

- недостатня матеріальна та технологічна забезпеченість діяльності лікарів, з метою визначення найбільш необхідних елементів в його діяльності на думку експертів;

- наявність фактів значного погіршення здоров’я населення, яке підлягає обслуговуванню в даній лікарні;

- невдоволення працівників умовами роботи, тощо. 


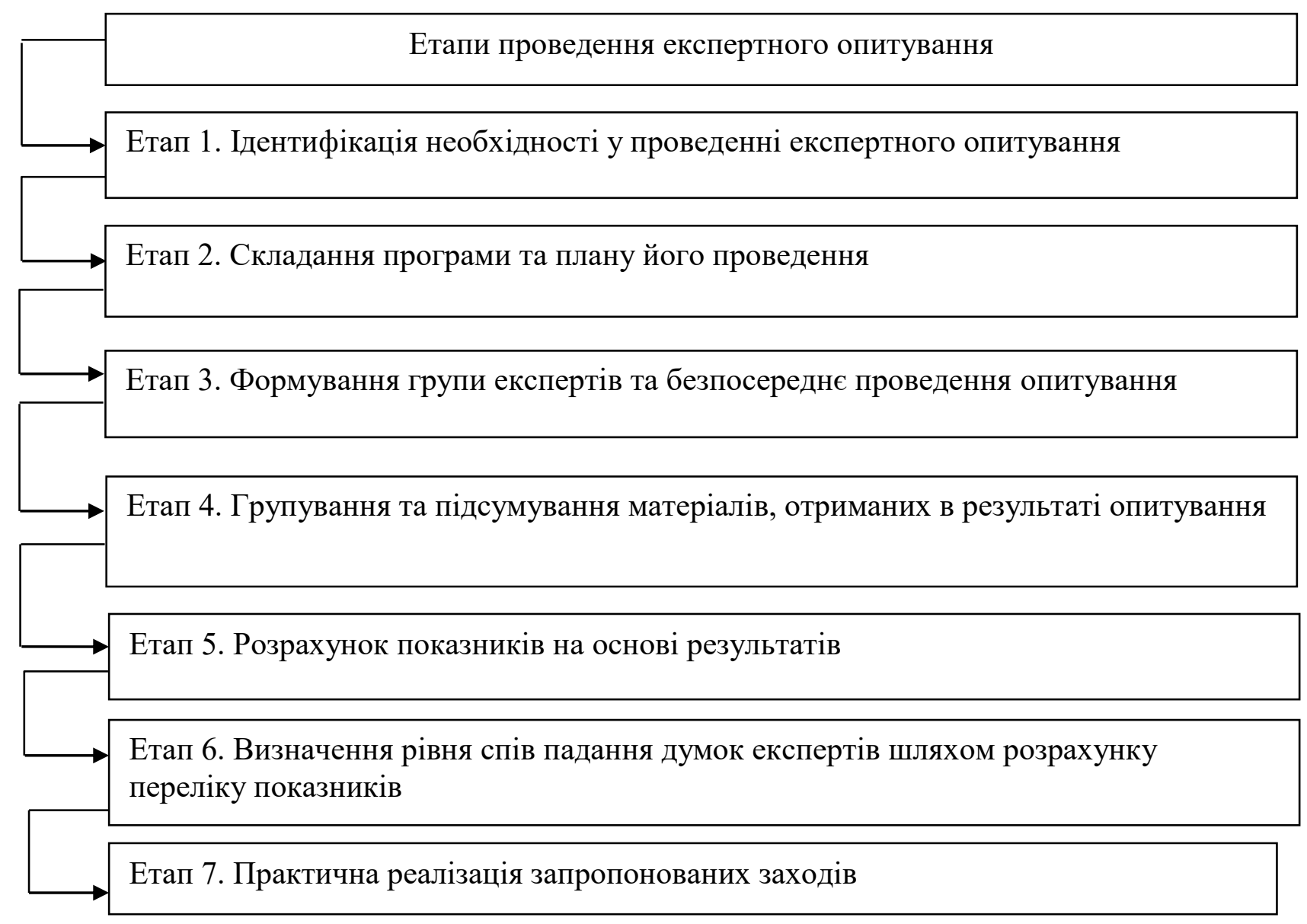

Рис. 1. Етапи процесу експертного опитування щодо діяльності багатопрофільної лікарні

* Джерело: власна розробка автора на основі [6, с.32]

Залежно від визначеної проблеми складається програма та план проведення експертного опитування. В межах даного етапу відбувається визначення мети та завдань експертного опитування. У нашому випадку, метою його проведення виступає пошук можливих шляхів вирішення проблем на шляху до оптимізації показників діяльності багатопрофільного медичного закладу. Завданнями експертного опитування $є$ :

- отримання висококваліфікованих даних щодо можливих шляхів вирішення наявних проблем у діяльності;

- одержання незалежного погляду зі сторони, з метою виявлення тих частин проблеми, які перебуваються за межами поля зору керівників та працівників лікарні;

- формування чіткого переліку високоефективних заходів для покращення діяльності медичної установи;

- пошук додаткових джерел, як матеріальних, так й інформаційних для оптимізації діяльності багатопрофільного закладу охорони здоров’я. 
Окрім того, на другому етапі відбувається формування анкетиопитувальника з визначеним переліком запитань, які в майбутньому надаються експерту. Відповіді на запропоновані запитання розглядаються як дані, про ступінь впевненості експерта у ймовірності розвитку якоїсь конкретної події, або ступеня їі важливості [3, с. 92].

Для прикладу, запитання в анкеті-опитувальнику можуть бути побудовані наступним чином:

1. Опишіть обов’язкові елементи виконання якісної роботи лікарем будьякого профілю (для прикладу оториноларинголога, хірурга, анестезіолога, тощо) .

2. Який ступінь впливу на рівень невдоволеності пацієнтів має відсутність необхідного обладнання для проведення повноцінного лікування у спеціалізованого лікаря. Виберіть один із варіантів: 1 - взагалі немає; 2 незначний вплив; 3 - помірний вплив; 4 - впливає значною мірою.

3. Що на вашу думку, значною мірою вплинуло на підвищення кількості звернень пацієнтів із лор-проблемами протягом останнього кварталу.

Дані питання повинні вибудовуватись навколо визначеного напрямку проведення експертного опитування. При цьому їх кількість може коливатись від одного до декількох десятків.

На третьому етапі соціологічного опитування відбувається відбір експертів, а також відбувається оцінка їх компетентності. Дана оцінка може здійснюватись об'єктивним та суб'єктивним способом (рис.2).

Щодо об’єктивного способу, то метод документальної оцінки передбачає відбір експертів на основі їх кваліфікаційних характеристик в медичній галузі. Тут важливу роль відіграє наявність атестаційної категорії, наукового ступеня, стажу роботи, тощо. В той же час, експериментальний метод передбачає оцінку ефективності діяльності експерта в минулому. Недоліком його застосування $\epsilon$ нехтування новими кваліфікованими кадрами, які ще не брали участі в експертних опитуваннях. 

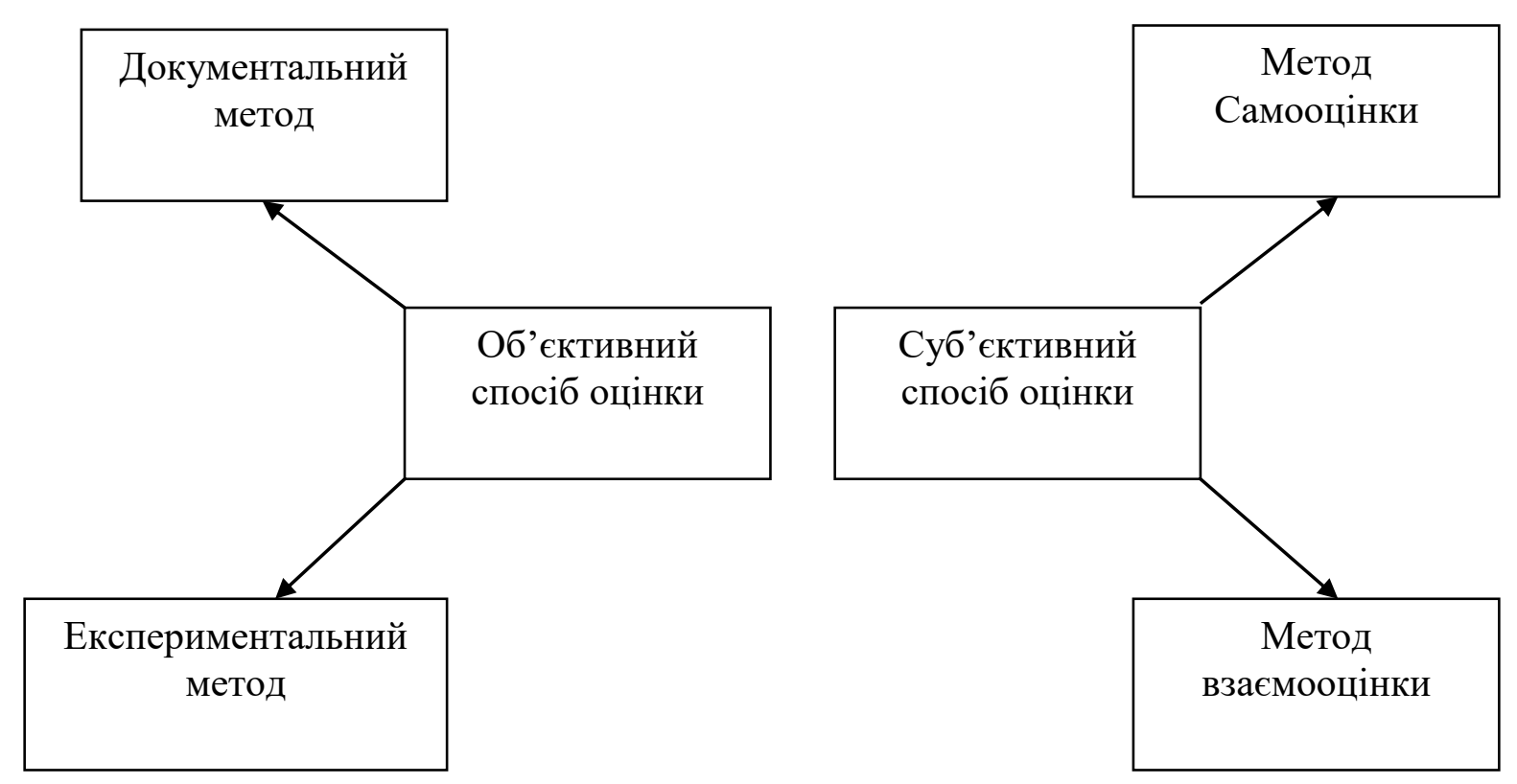

Рис. 2. Способи оцінки компетентності експертів

* Джерело: власна розробка автора на основі [2, с.100]

Якщо мова йде про спосіб суб'єктивної оцінки, то він може проводитись методом само та взаємооцінки. Під час проведення самооцінки, експерт власноруч визначає вагомість своєї оцінки, тоді як при взаємооцінці характеристики надаються спеціалісту його колегами [2, с.101]. Характерною рисою методу самооцінки $є$ також визначення ступеня впливу різних джерел інформації на думку експерта.

Поруч із цим, експерт повинен володіти наступними якостями [6, с.34]:

1. Креативність, яка передбачає вміння нестандартно вирішувати наявні проблеми, шляхом застосовування невідомих або маловідомих методів.

2. Еврестичність, яка виражається у здатності виокремлювати неочевидні проблеми.

3. Хороша інтуїція, яка дозволяє приймати рішення без знання всіх аспектів проблематики опитування.

4. Передбачуваність, а іншими словами вміння прогнозувати стан об'єкта дослідження у майбутньому.

5. Незалежність, яка виражається у відсутності впливу на думку експерта загальноприйнятих постулатів та думки громадськості.

6. Всеобізнаність - здатність аналізувати проблему під різним кутом.

Окрім вищезазначеного, на даному етапі відбувається власне саме проведення експертного опитування одним із обраних методів. Серед методів, які використовуються для проведення експертних опитувань виділяють заочні 
та очні. В межах кожного із них виділяють специфічні підвиди, схематичне зображення яких отримуємо з рис.3.

Розглянемо детальніше деякі із них 3 позиції визначення доцільності їх застосування для оцінки основних показників оптимізації роботи багатопрофільного медичного закладу.

Отже, розпочнемо із методу письмового опитування, який за своєю сутністю $є$ найбільш простим із всіх вищеперерахованих методів. Суть його полягає в тому, що обраному колу експертів розсилаються спеціально підготовлені опитувальні листи, в яких вони зазначають свою думку з приводу запропонованих у ньому запитань. В той же час, при складанні даного опитувальника застосовується від 50 до 90 відсотків відкритих питань [7]. Даний вид схожий із інтерв`ю, маючи лише одну відмінну рису, що даний метод проводиться у письмовій формі, яка дозволяє залучити до опитування велику кількість експертів.

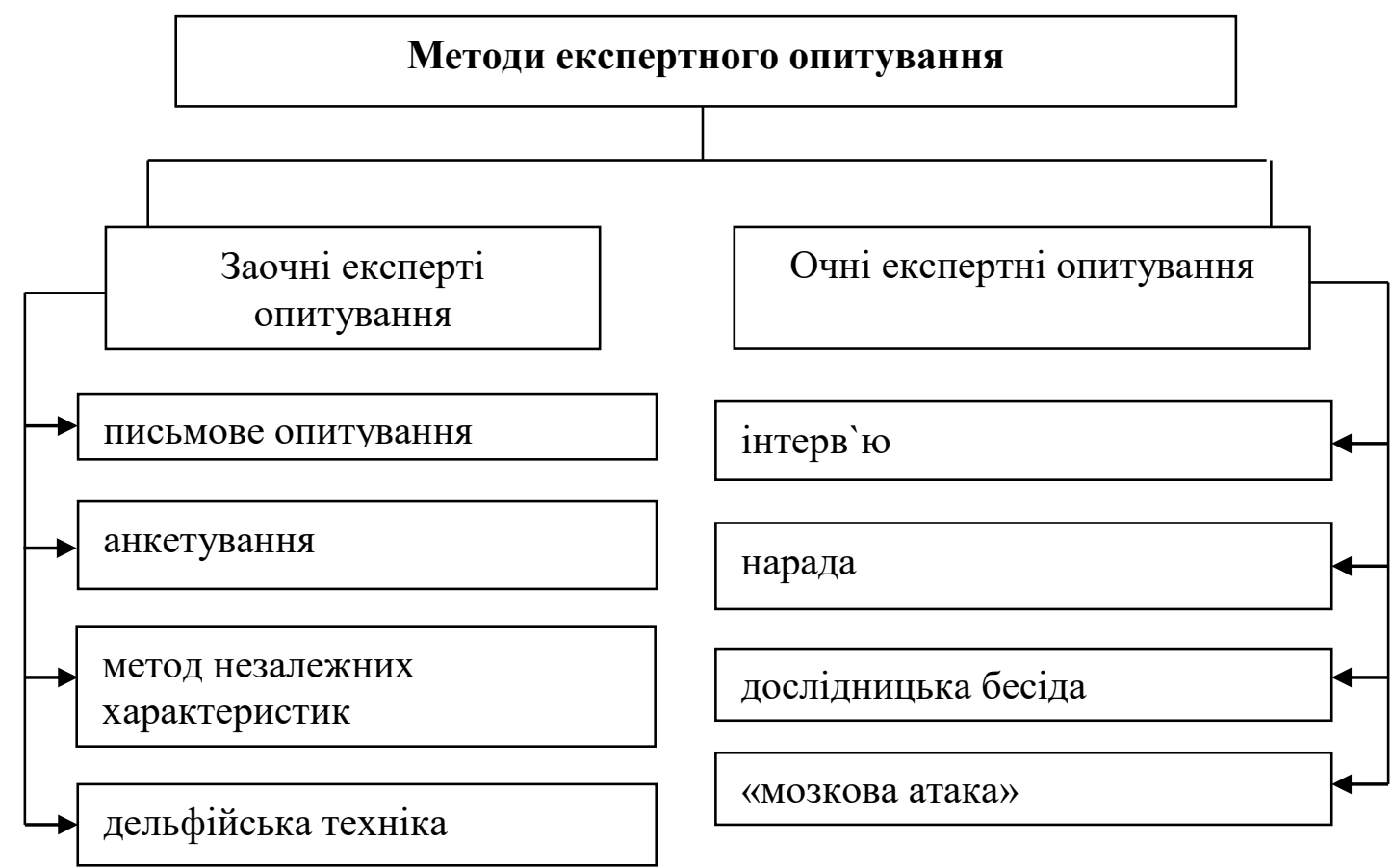

Рис. 3. Методи експертного опитування

* Джерело: власна розробка автора на основі [7]

Недоліком даного методу є те, що при його застосування необхідно забезпечити роботу складної організаційної структури, тому що в протилежному випадку буде низьке повернення опитувальників. Щодо застосування даного методу для наших потреб, то застосування його можливе, проте буде натикатись на таку перешкоду як необхідність залучення великої 
кількості фахівців саме медичної сфери, а це розширює границі проведення дослідження і в підсумку може вплинути на його розпорошеність.

У випадку застосування методу анкетування, то тут питання можуть задаватись як у відкритій так і в закритій формі [7]. За поставленими цілями, завданнями та змістом даний метод значно відрізняється від попереднього. Так, ціллю письмового опитування є виявлення принципово нових ідей, поглядів підходів до вирішення проблем, а метою анкетування, в свою чергу, $\epsilon$ з'ясування оцінок тих чи інших аспектів вже готових прийнятих рішень. 3 цієї позиції даний метод $\epsilon$ одним із найбільш прийнятних для проведення експертних опитувань у багатопрофільних медичних закладах через те, що отримується можливість проаналізувати поточну ситуацію та сформувати шляхи їі покращення.

Метод незалежних характеристик дозволяє дати узагальнену оцінку одного явища, інформація про який надходить 3 декількох незалежних джерел (або від різних людей). На першому етапі його проведення відбувається порівняння і зіставлення різних думок, на другому їх обробка із використанням математично-статистичних прийомів, а на заключному - третьому етапі відбувається формування висновків щодо об’єкта дослідження [7]. Проте, даний метод частіше за все використовується для оцінки індивіда, і не може бути адаптований під потреба багатопрофільного медичного закладу.

Заключним методом заочних експертних опитувань $є$ дельфійська техніка, яка передбачає опитування експертів у кілька турів, із обробкою результатів кожного туру, подальшим інформування експертів про одержані результати і знову повторення такої ж процедури. У першому турі відповідь на запитання необхідно надати в балах, при цьому не здійснюючи ніякої аргументації. Після обробки даних, отриманих в ході першого туру, формуються граничні й середні судження, які повідомляються експертам [6, c.35]. Іншими словами, за результатами першого туру визначається частка експертів, які дали найвищий та найнижчий бал, з подальшим повідомленням їх, що їхня відповідь виходить за межі усередненої відповіді та пропонуються обгрунтувати причини розбіжності в поглядах із можливістю зміни кінцевої відповіді.

Після другого туру обробляються нові оцінки: крайні і середні думки узагальнюються, підсумки знову доповідають експертам. Важливою рисою даного методу $є$ те, що між першим та другим туром експерти мали час переглянути свої погляди, а також дізнались про існування думок відмінних від їхніх. Описана процедура повторюється 3-4 рази [6, с.34]. Як показує практика, після третього або четвертого туру думки експертів не міняються. У ході 
подібної процедури виробляється узгоджена оцінка, при цьому дослідник не повинен ігнорувати думку тих, хто після неодноразових опитувань залишився на своїй позиції. Даний метод, незважаючи на складність, часто застосовується до оцінки діяльності закладів охорони здоров`я, в тому числі i для багатопрофільних медичних закладів.

Метод інтерв’ю, який входить до очних експертних опитувань, передбачає опитування за різними типами питань, зокрема такими, приклад яких наведений вище в даному дослідженні. Цікавим фактом є те, що найбільш точні та продумані відповіді надаються експертом після пів хвилинних роздумів над запитанням [8]. Практика застосування даного методу є також досить поширеною, адже дозволяє співпрацювати напрямку з обраною групою експертів, що підвищує результативність дослідження.

Нарада та дослідницька бесіда, є схожими до вищезазначеного методу, проте носять більш відкритий характер, застосування якого не прийнято у вітчизняній практиці. Окрім того, дані методи не виключають можливість впливу на думку експерта загальної думки, що негативно позначається на об'єктивності його висновків.

Заключним методом, який нами розглядається є метод «мозкової атаки» , під час використання якого визначається загальна проблема діяльності багатопрофільного медичного закладу, про яку знають як керівництво так i медичні працівники, і яка обговорюється групою обраних експертів. При цьому, ні одна ідея не піддається критиці, а навіть навпаки - всі ідеї схвалюються. Застосування даного методу дає змогу підвищити продуктивність експертів, так як поширеною є думка, що більша кількість ефективних ідей виникає тоді, коли аналізуються лише ефективні ідеї. Даний метод застосовується досить рідко для потреб медичної галузі так як обговорення специфічних проблем галузі охорони здоров’я викликає багато суперечностей, які в межах діяльності одного закладу охорони здоров'я вирішити дуже складно.

Окрім того, той факт, що в результаті мозкової атаки висувається досить довгий список ідей також не на користь використання даного методу, адже така ситуація поставить перед керівником закладу охорони здоров'я нову проблему у виборі серед існуючих пропозицій. Наявність такого вибору знецінює думки експертів, адже основною метою їх залучення було розробка конкретних пропозиції по оптимізація діяльності медичного закладу, чого на практиці не відбувається.

Таким чином, можемо підсумувати що для потреб отримання експертної оцінки з приводу основних показників оптимізації роботи багатопрофільного 
медичного закладу найбільш прийнятними є такі методи як, анкетування, та дельфійська техніка. Інші методи застосовувати можливо, проте в цьому випадку процес експертного опитування може бути складнішим або не настільки точним.

Наступним етапом експертного опитування є групування та підсумування результатів опитування. На цьому етапі проводиться обробка всіх отриманих даних у вигляді анкет та опитувальників, їх групування за критерієм спів падіння результатів, а також проводиться аналіз кількості тотожних думок шляхом вираховування їх відсоткового співвідношення. На цьому етапі важливим є отримання відповіді на запитання [8]:

1. Яку думку висловили експерти.

2. Чи можна дану думку вважати достовірною та взяти іiі за основу для прийняття рішення.

Після виконання цих дій, переходимо до етапу розрахунку показників на основі результатів експертного опитування. Тут роль відіграє в якій формі були поставлені запитання. Якщо у вигляді простої відповіді «так» або «ні», то нам для проведення аналізу необхідно використовувати відносні показники, а саме інтенсивні показники та показники співвідношення. У випадку використання бальної оцінки, для отримання середнього значення суму всіх думок експертів у балах ділять на кількість експертів [8].

Окрім того, може бути випадок, коли використовують градацію важливості думок експертів, відповідно до їх посади. Так, думка доктора наук, головного лікаря буде мати більше значення ніж кандидата у доктори наук, лікаря - спеціаліста у певному напрямку, тощо.

При цьому під час розрахунки середнього значення результату дослідження кожну думку експерта в балах множать на ваговий коефіцієнт розрахований для його наукового ступеня чи посади і в підсумку ділять на кількість експертів [6, с.36].

На шостому етапі відбувається оцінка спів падання думок шляхом розрахунку таких статистичних показників, як середнє квадратичне відхилення та коефіцієнт варіації [5, с.112].

. Проведемо наочне відображення вищеописаних етапів на прикладі проблеми багатопрофільного медичного закладу, яка пов'язана із відсутністю у лікарів медичного закладу необхідного обладнання, а саме проведемо експертне опитування яким чином вплине купівля обладнання для проведення експрес-аналізів крові пацієнтів на оптимізацію роботи досліджуваного закладу охорони здоров`я. Свої думки експерти повинні зазначити в опитувальнику присвоївши бали відповідно до важливості купівлі даного обладнання від 10 до 
0. Серед експертів опитуємо директорів приватних клінічних лабораторій, головних лікарів медичних закладів, які вже мають дане обладнання, завідувача лабораторії багатопрофільного медичного закладу.

Таким чином, за результатами опитування ідею необхідності купівлі такого обладнання підтримали всі експерти. При цьому середній показник важливості такого придбання із використанням шкали вагомості експертів склав 8,95 $\pm 0,54$ бали. У структурі оцінювання найвищу кількість балів поставили 40 \% експертів, а найнижчу - 9,3\% спеціалістів. Проведення аналізу розбіжності думок експертів шляхом розрахунку коефіцієнту варіації у підсумку складає 19,15\%, що показує достатній рівень спів падання думок експертів, що в свою чергу свідчить про необхідність купівлі обладнання для проведення експрес-аналізів крові.

Купівля даного обладнання на думку $89,0 \pm 4,3 \%$ опитаних експертів дасть змогу значною мірою розвантажити діючу лабораторію (орієнтовано на $54 \pm 3,0 \%)$, дозволить підвищити швидкість проведення лабораторних досліджень, що підтримують 100 \% експертів. Окрім того, дозволить налагодити потоки клінічних досліджень між пацієнтом та його лікарем - що підтверджується $87 \pm 3,9 \%$ експертів.

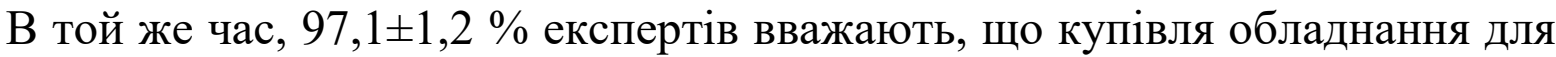
проведення експрес-тестування позитивно вплине на імідж багатопрофільного медичного закладу в регіоні його дислокації, а 94,3 $\pm 2,2$ \% опитаних стверджують що така операція дозволить збільшити якість послуг, які надаються даною медичною установою за рахунок підвищення швидкості та точності результатів.

Отже, на основі вищевикладеного приймається рішення про практичну реалізацію запропонованого заходу шляхом фактичного придбання обладнання для експрес-тестування, що складає собою заключний етап експрес опитування. Таким чином, формування експертної оцінки щодо доцільності придбання нового обладнання стало основою для оптимізації роботи багатопрофільного медичного закладу в частині підвищення здатності у проведенні лабораторних досліджень у день, зменшенні часу на його проведення, підвищення якості послуг медичної установи, що є позитивним.

3 наведеного вище, бачимо, що процес експертного опитування є досить складним та багатоетапним, а отже для його проведення потрібно значні затрати часу, а подекуди й ресурсів. Саме тому, перед прийняттям рішення про початок даного виду дослідження необхідно повною мірою оцінити можливі затрати та результат. 
Висновки 3 проведеного дослідження. Підсумовуючи дані, наведені в науковому дослідженні зазначимо, що заклади охорони здоров'я не завжди можуть вирішувати проблеми, з якими стикаються в процесі своєї діяльності самостійними силами. Відтак, виникає необхідність звернення до сторонніх людей - спеціалістів у медичній сфері, які повинні допомогти якомога ефективніше вирішити ситуацію, яка склалась. На допомогу в цьому процесі приходить експерте опитування, яке має чіткий механізм його проведення.

Отже, експертне опитування в закладі охорони здоров'я починається із виявлення необхідності у його проведенні. Наступним кроком $є$ складання програми та плану проведення експертного опитування поруч із формуванням групи експертів. На етапі безпосереднього проведення 3-поміж широкого переліку методів здійснення експертного опитування відбувається вибір найбільш прийнятного для виявленої проблеми та потреб установи охорони здоров'я, зокрема багатопрофільного медичного закладу. Після проведення опитування виникає необхідність групування та підсумування матеріалів, для виявлення найбільш поширених тверджень й визначення відсоткового співвідношення між ними. Завершується цей процес практичною реалізацією запропонованих заходів. Таким чином, виконання всіх цих етапів дозволяє керівництву сформувати компетентну думку щодо ймовірних шляхів вирішення наявних проблем або відстежити яким чином запровадження певних заходів вплине на діяльність закладу охорони здоров'я загалом, що виступає одним із ключових факторів на шляху до оптимізації показників діяльності медичного закладу.

\section{Jimepamypa:}

1. Грабовецкий Б.С. Основи економічного прогнозування: навчальний посібник. Вінниця : ВФ ТАНГ, 2000. $468 \mathrm{c}$.

2. Гнатієнко Г.М., Снитюк В.Є. Експертні технології прийняття рішень. Київ : Маклаут, 2008. 444 c.

3. Добреньков B.I., Кравченко А.І. Методи соціологічного дослідження: підручник. Москва : ИНФРА-М, 2004. 768 с.

4. Маркетингова агентство Buro.MT. Проведення експертних опитувань. URL: https://buromt.com.ua/uk/expert-survey/(дата звернення 26.03.2020).

5. Реброва О.Ю. Статистический анализ медицинских данных. Применение пакета прикладных программ STATISTICA. Москва : Медиа Сфера, 2002. 312 с.

6. Рудень В.В., Гутор Т.Г. Методика проведення та оцінки результатів експертних оцінок (на прикладі впровадження системи моніторингу здоровя населення на рівні первинної медико-санітарної допомоги). Львівський національний медичний університет ім. Данила Галищького. 2001. №2 (82) III - IV. C. 31-38.

7. Толстих H. В. Експертні опитування. URL: http://isoc.com.ua/school/Tolstyh_Expert.pdf. (дата звернення 26.03.2020). 
8. Slaidik. Блог про інтернет-маркетинг. Як провести експертне опитування: покрокове керівництво із прикладами з нашої практики. URL: http://slaidik.com.ua/yak-provesti-ekspertneopituvannya-pokrokove-kerivnitstvo-z-prikladami-z-nashoyi-praktiki/l (дата звернення 25.03.2020).

\section{References:}

1. Hrabovetskyi, B.Ye. (2000). Osnovy ekonomichnoho prohnozuvannia [Basics of economic forecasting]. Vinnytsia: VF TANH [in Ukrainian].

2. Hnatiienko, H.M., Snytiuk, V.Ye. (2008). Ekspertni tekhnolohii pryiniattia rishen [Expert decision-making technologies]. Kyiv: Maklaut [in Ukrainian].

3. Dobren'kov V.I., Kravchenko A.I. (2004). Metody sotsiologicheskogo issledovaniya [Methods of sociological research]. Moscow: INFRA-M [in Russian].

4. Provedennia ekspertnykh opytuvan [Conducting expert surveys]. (n.d.). buromt.com.ua. Retrieved from https://buromt.com.ua/uk/expert-survey/ [in Ukrainian].

5. Rebrova, O.Yu. (2002). Statisticheskiy analiz meditsinskikh dannykh. Primenenie paketa prikladnykh programm STATISTICA [Statistical analysis of medical data. Application of the STATISTICA application package]. Moscow: Media Sfera [in Russian].

6. Ruden, V.V., Hutor, T.H. (2001). Metodyka provedennia ta otsinky rezultativ ekspertnykh otsinok (na prykladi vprovadzhennia systemy monitorynhu zdorovia naselennia na rivni pervynnoi medyko-sanitarnoi dopomohy) [Methods of conducting and evaluating the results of expert assessments (for example, implementation of the system of monitoring the health of the population at the level of primary health care)]. Ukrainskyi medychnyi chasopys - Ukrainian Medical Journal, 2(82), 31-38 [in Ukrainian].

7. Tolstykh, N.V. (n.d.). Ekspertni opytuvannia [Expert surveys]. i-soc.com.ua. Retrieved from http://i-soc.com.ua/school/Tolstyh_Expert.pdf [in Ukrainian].

8. Yak provesty ekspertne opytuvannia: pokrokove kerivnytstvo iz prykladamy $\mathrm{z}$ nashoi praktyky [How to conduct an expert survey: a step-by-step guide with examples from our practice]. (2020). slaidik.com.ua. Retrieved from http://slaidik.com.ua/yak-provesti-ekspertne-opituvannyapokrokove-kerivnitstvo-z-prikladami-z-nashoyi-praktiki/ [in Ukrainian]. 